\title{
Sustainable Materials Selection for Canadian Construction Industry: An Emergy-Based Life-Cycle Analysis (Em-LCA) of Conventional and LEED Suggested Construction Materials
}

\author{
Navid Hossaini \\ School of Engineering, University of British Columbia \\ 1137Alumni Ave, Kelowna BC V1V 1V7, Canada \\ Tel: 1-250-899-3898 E-mail: navid.hossaini@ubc.ca \\ Kasun Hewage (Corresponding author) \\ School of Engineering, University of British Columbia \\ 1137 Alumni Ave, Kelowna BC V1V 1V7, Canada \\ Tel: 1-250-807-8176 E-mail: kasun.hewage@ubc.ca
}

Received: October 21, 2011

Accepted: November 21, $2011 \quad$ Published: January 1, 2012

doi:10.5539/jsd.v5n1p2

URL: http://dx.doi.org/10.5539/jsd.v5n1p2

\begin{abstract}
Building industry is a major cause of ecological and environmental problems in the global scale. It accounts for $40 \%$ of material and $30 \%$ of global energy consumption. Emergy (spelled with an " $\mathrm{m}$ ") is the energy of one kind (usually solar energy) that is used, directly or indirectly, to make a product or service. The objective of this paper is to identify sustainable construction materials by assessing the specific emergy of major construction materials used in Canada, including a few rapidly renewable materials suggested by Leadership in Energy and Environmental Design (LEED). Lifecycle analysis (LCA) of the selected materials was carried out to identify all type of natural, human, and energy resources used in their production process. The specific emergy of each selected material was calculated using the corresponding transformity functions. Results show that rapidly renewable materials suggested by LEED should not be taken blindly without considering the location of construction.
\end{abstract}

Keywords: Emergy, Lifecycle analysis, Construction, Green buildings, LEED, Rapidly renewable materials

\section{Introduction}

As the world population increases, need for all types of infrastructure increases exponentially. After food, a shelter or home is the most basic need of every human. The building industry consumes large portion of limited reserves in the world. It accounts for $30-40 \%$ of all natural resources used in developed countries. This includes almost $40 \%$ of all material, $30 \%$ of energy, and $70 \%$ electricity consumption in the world (Roodman $\&$ Lenssen, 1995). This is just a part of the problem; buildings do not only consume limited resources, but also create environmental pollution. According to the United States Green Building Council (USGBC, 2007), building sector accounts for $30 \%$ of all greenhouse gas emissions and $45-60 \%$ of land filled waste. Because of the resource scarcity, there is an urgent need for paradigm shift towards sustainability and 'green' buildings, since on average green buildings consume 30\% less energy, 30-50\% less water, and produce 35\% less carbon emissions (USGBC, 2007).

There are various indicators applied to the building industry to evaluate its' sustainability performance. Buildings are categorized as "green" if they meet sustainability criteria defined by assessment tools/frameworks. Among all of building sustainability grading systems (Level 3), LEED developed by USGBC in 2000 is the current leading system in the North America, mainly due to its simplicity to use.

Although LEED is the most common building rating system, it has its own drawbacks. Chew and Das (2007) pointed out two main problems of LEED; first is 'point hunting', where a building can achieve required points for certification without addressing crucial points of energy efficiency. Secondly, points are lost for credits that are outside the scope of a certain project. Moreover, Newsham et al. (2009) studied 100 LEED-certified buildings on energy use and discovered that although on average LEED-certified buildings consume 18 -39\% less 
energy compared to non-certified buildings, $28-35 \%$ of LEED-certified buildings actually use more energy than conventional buildings. Authors also found a weak relationship between the energy performance of LEED-certified buildings and received energy points from the rating system. They concluded that these weaknesses question the credibility of current green building rating systems and believe there is a need for a stronger sustainability rating system. Due to the above pointed weaknesses in current sustainability rating systems, the construction industry needs a more comprehensive method that covers lifecycle of building materials and provides a better estimation of building's environmental impact. The solution may be developing an emergy based building grading system. To develop Emergy based sustainability system, it is necessary to create an emergy database for major materials currently used in the construction industry, including suggested green materials by LEED for comparison purposes.

In this paper Emergy-based Life Cycle Analysis (Em-LCA) for both conventional and LEED suggested construction materials is presented. Emergy results of materials with the same structural properties are compared to find the option with lowest environmental impact in Canada.

\section{Background}

Following is a brief background on current building rating systems and emergy based lifecycle analysis.

\subsection{Building Rating Systems}

The need for more buildings as global population increases is undeniable. Since buildings consume enormous amounts of limited natural resources, switching towards sustainable (also referred to as green) buildings are an urgent need. Yudelson (2008) defined green building as a "high-performance property that considers and reduces its impact on the environment and human health." A green building is a structure that is environmentally responsible and resource efficient throughout its life cycle, as shown in Figure 1 (US EPA, 2009).

The concept of sustainable buildings came into existence in early 1980s and the idea to develop rating systems to evaluate sustainability performance of buildings became popular in the early 1990s (Yudelson, 2008). Chew and Das (2007) provided a review of building grading systems since 1990 and discussed the "scope, limitation, and working principle" of current rating systems. The authors divided building grading systems into three generations; i.e. (1) pass-fail, (2) simple additive, and (3) weighted additive systems. Table 1 provides a summary of the major grading systems in the world.

\subsection{LEED and Green Construction Materials}

Among various building grading systems, LEED, developed by USGBC, is the current leading system in the North America. LEED provides a point-based framework to evaluate buildings performance in six main categories: (1) sustainable sites, (2) water conservation, (3) energy and atmosphere, (4) materials and resources, (5) indoor environmental quality and (6) innovation in design and regional priority. The building can receive various levels of certification based on its overall points from all categories (i.e. certified, silver, gold, and platinum certifications).

LEED for new construction and major renovations suggested a list of 'rapidly renewable materials' (under MR Credit 6) for the use in green buildings. The main intention of using these materials is to reduce the use and depletion of finite raw materials and long-cycle renewable materials (USGBC, 2009). Suggested rapidly renewable materials by LEED are bamboo, linoleum, wool, cotton insulation, agri-fiber, wheat board, strawboard, and cork. Among these materials, bamboo and linoleum were selected for emergy analysis of this study since they are gaining popularity to replace conventional flooring and structural materials in North America. If necessary, similar emergy analysis can be performed for the remaining rapidly renewable materials suggested by LEED.

Concrete is used more than any other man-made material in the world (Lomborg, 2001) and the cement industry releases about $5 \%$ of the world $\mathrm{CO}_{2}$ emissions (Pulselli et al., 2008). LEED does not suggest an alternative for Portland cement concrete currently used in the building industry. In this paper, emergy analysis of High Volume Fly Ash (HVFA) concrete, which is commonly referred to as a "green" concrete, is compared with Portland cement concrete to find the most sustainable option for the Canadian construction industry.

\subsubsection{Bamboo}

Bamboo (as shown in Figure 2a) is a fast growing renewable material that can be used as a sustainable alternative for traditional structural materials, such as concrete, steel and wood (Van der Lugt et al., 2005). Strength, durability and rapid growth rate of bamboo makes it an 'environmental friendlier' alternative compared 
to conventional structural materials. Bamboo is a very strong natural material that has twice the compressive strength of concrete and almost the same strength to weight ratio of steel in tension (Kubba, 2010).

\subsubsection{Linoleum}

Linoleum (Figure 2b) is a natural material that is mainly used for flooring. Linoleum has many advantages over other flooring materials, such as flexible vinyl flooring and tiles, recyclable at the end of its life cycle, more durable and much lower Volatile Organic Compound (VOC) emissions (Kubba, 2010).

\subsubsection{High Volume Fly Ash (HVFA) Concrete}

Beside rapidly renewable materials suggested by LEED, HVFA concrete (also referred to as green concrete) is suggested to replace normal Portland cement concrete in sustainable structures (Mehta, 2002). In HVFA concrete, high portion of cement (50-70\%) is replaced by fly ash. Fly ash is a very fine binder powder produced from coal combustion. In modern thermal power plants fly ash does not need additional processing before being used in concrete. Therefore it is considered as an environmental friendly material from LCA point of view (NIST, 2003).

\subsection{Emergy Analysis}

By definition, "emergy is the available energy of one kind that has been used up directly and indirectly to make a product or service" (Odum, 1996). Emergy uses the thermodynamic basis of all forms of energy and materials, but converts them into equivalents of one form of energy. The most common method is transforming all inputs to solar energy (called solar emergy joule or 'sej') (Pulselli et al., 2008).

The emergy of different products is calculated by multiplying mass $(\mathrm{g})$ or energy quantities $(\mathrm{J})$ by transformity, which is a transformation coefficient. Transformity is the solar emergy required, directly or indirectly, to make one joule or one gram of a product or service.

By definition, the solar emergy $\mathrm{B}_{\mathrm{k}}$ of the flow $k$ coming from a given process is:

$$
B_{k}=\sum_{i} \operatorname{Tr}_{i} E_{i} \quad i=1,2, \ldots, n
$$

Where, $E_{i}$ is the actual energy content of the $\mathrm{i}^{\text {th }}$ independent input flow to the process and $\operatorname{Tr}_{\mathrm{i}}$ is the solar transformity of the $\mathrm{i}^{\text {th }}$ input flow (Pulselli et al., 2007).

Among different evaluation methods, such as exergy, emergy, and embodied energy, emergy was chosen for the analysis presented in this paper because of its ability to normalize all products and services into a single unit. Emergy concept overcomes use of variety of units to quantify different inputs including materials, energy, and human services (Tilley \& Swank, 2003).

The main use of exergy is for energy conversion systems, such as power plants where the major input is fossil fuels and major outputs are electricity or thermal power. Compare to emergy, exergy does not account for "goods and services in the market, or information required" for a system (Meillaud \& Brown, 2005). Detailed comparison of emergy and exergy is available in the literature by Ulgiati (2000).

Embodied energy is defined as the total energy (including fossil fuels, solar, nuclear, etc.) that was used in the work to make any product, bring it to market and dispose. Therefore, embodied energy does not consider other inputs used to make a product or service such as material, human workand information. Detailed comparison of emergy and embodied energy is performed by Brown and Herendeen (1996). Studies conducted on emergy analysis related to construction industry are summarized in Table 2.

In reference to buildings, Pulselli et al. (2007) performed emergy analysis to evaluate a typical residential/commercial building in central Italy during its construction, maintenance and use phases. The authors used emergy analysis as a form of sustainability indicator, while common building evaluation methods, such as LEED, follow state-pressure environmental indicators. Authors key finding from this analysis is that durability of material (life time) is an essential element of sustainability, since a longer building life span corresponds to lower annual emergy inflow for building manufacturing stage. Also, Meillaud and Brown (2005) applied emergy analysis to evaluate an educational building located in Institute of Technology of Lausanne in Switzerland. The authors chose emergy since it accounts for both economical and information flows in addition to conventional environmental flows. Analysis result was expressed in three forms of unit emergy values: transformity, specific emergy, and emergy per unit money. Authors' major conclusion was that information has the highest emergy inputs to the building, followed by human services and operating energies. 


\section{Methodology}

Following steps were performed to analyze and calculate specific emergy of construction materials.

\subsection{Material Selection}

Construction materials chosen for this study was divided in two categories:

(1) Major construction materials in Canada: The major construction materials were chosen from a published list of building materials in Canada by Norman et al. (2006). Emergy analysis for five most used construction materialswas conducted. The selected materials were Portland cement concrete, plywood, reinforcing bar, structural steel, and brick.

(2) Green building materials: three materials were selected asgreen alternatives to common construction materials in flooring and structural systems. Bamboo and Linoleum were selected from LEED suggested rapidly renewable materials. In addition, HVFA concrete was selected as a green substitute for Portland cement concrete. Table 3 shows mixture proportion of Portland cement and HVFA concrete used in this study.

\subsection{Life Cycle Analysis}

Lifecycle analysis, for all the selected materials, was conducted by using Sima Pro 7.1. The analysis considered all resources consumed by a particular material up to delivery point to aconstruction site. Resources include all types of material and energy consumptions in different lifecycle stages of selected construction materials. Initial LCA for green materials, that are not available in Sima Pro 7.1 database, were found from literature. This includes initial LCA of HVFA concrete by Chen et al. (2010), Linoleum by Jonsson et al. (1996), and Bamboo by Vogtländer et al. (2010).

\subsection{Emergy Calculations}

Emergy analysis for each construction material was performed considering four major inputs: material, energy, transportation, and human work.

Specific emergy for transportation of building materials for a vehicle (25 tones capacity) was calculated per distance with reference to Pulselli et al. (2007). Emergy of human work was estimated as:

Human metabolism $(125 \mathrm{kcal} / \mathrm{h})$ * energy per cal $(4.186 \mathrm{~J} / \mathrm{kcal})$ * typical human work $/ \mathrm{kg}$ of concrete production $(0.000146 \mathrm{~h})=0.08 \mathrm{Joules} / \mathrm{kg}$ of concrete

Finally, Emergy of material and energy inflows was calculated based on LCA outputs using transformity values available in the literature with reference to: a (Odum, 1992), b (Buranakarn, 1998), c (Odum, 1996), d (Ulgiati et al, 1994), e (Odum \& Arding, 1991), f (Tiezzi, 2001), g (Ulgiati et al., 1993) and h (Pulselli et al., 2007).

Figure 3 shows the methodology for this study.

\section{Results and Discussion}

Specific emergy values for both groups of construction materials were calculated using emergy transformity functions. The results are shown in Table 4 . Table 4 is divided into four sections, showing emergy value from each inflow of material, energy, transportation, and human work separately.

Materials account for almost three-quarter and energy inflow accounts for almost one-quarter of specific emergy of Portland cement concrete. Results show that emergy of transportation is very low and negligible. This is due to short transportation distance between concrete production plant and construction site $(100 \mathrm{~km})$. Similarly, human work has negligible emergy and accordingly very low environmental impact.

Specific emergy of other construction materials more or less follow the same trend as Portland cement concrete, where emergy from material and energy inputs are the major contributors. Specific emergy for both groups of construction materials is shown in Figure 4.

\subsection{Specific Emergy of Concrete}

The specific emergy of Portland cement concrete was found as $1.89 \times 10^{9} \mathrm{sej} / \mathrm{g}$. Table 5 shows specific emergy of concrete from various other studies found in the literature. Main reason for variation in these values is due to differences in type and properties of concrete in the study, such as cement content, density, and compressive strength.

\subsection{Comparison of Conventional and Green Materials}

In this section emergy of conventional construction materials is compared with their alternative 'green' materials. Figure 4 shows emergy compression of conventional and green construction materials. 


\subsubsection{Portland Cement and HVFA Concrete}

Specific emergy of HVFA concrete $\left(1.35 \times 10^{9} \mathrm{sej} / \mathrm{g}\right)$ is significantly less than Portland cement concrete $\left(1.89 \times 10^{9}\right.$ $\mathrm{sej} / \mathrm{g}$ ), which indicates that overall less energy and material is consumed to produce HVFA concrete. Therefore it has lower environmental impact and can be considered as a green alternative for Portland cement concrete. Considering that fly ash is a byproduct of coal combustion, HVFA is more economical too. Usage of HVFA concrete in green buildings helps to reduce environmental footprint of a structure, since concrete is the most used construction material in Canada.

\subsubsection{Tile and Linoleum (Flooring Materials)}

Flooring is an important part of construction. Since it covers large area of buildings, its contribution to buildings' overall environmental impact is significant. Currently, ceramic tiles are used as one of the main flooring material in building construction in Canada. Specific emergy of tile is calculated as $3.68 \times 10^{9} \mathrm{sej} / \mathrm{g}$ (Brown \& Buranakarn, 2003). LEED suggested linoleum, as a rapidly renewable material, for flooring. Comparing specific emergy of these two flooring materials show that linoleum with specific emergy of $2.78 \times 10^{9} \mathrm{sej} / \mathrm{g}$ is a sustainable option for flooring. Production of linoleum does not only require less natural, energy, and human resources, but also has lower environmental emission than ceramic tiles.

\subsubsection{Plywood and Bamboo (Structural Materials)}

Plywood and bamboo can be used as load bearing materials in structural systems due to their high compressive strength. As per calculations, specific emergy of plywood and bamboo are $2.66 \times 10^{9} \mathrm{sej} / \mathrm{g}$ and $4.37 \mathrm{x} 10^{9} \mathrm{sej} / \mathrm{g}$, respectively. Comparison of specific emergies of plywood and bamboo indicates that even though bamboo is one of the rapidly renewable materials suggested by LEED, it has almost twice the specific emergy of plywood. In other words, production of bamboo requires more environmental work than plywood, if used in Canadian construction industry. This is due to high emergy in transporting bamboo from either East Asia or South America to Canada. Transportation emergy for bamboo is $2.36 \times 10^{9} \mathrm{sej} / \mathrm{g}$, compare to $0.00919 \times 10^{9} \mathrm{sej} / \mathrm{g}$ for plywood as a locally produced material in Canada.

\section{Conclusion}

In this paper, specific emergies of major building materials in Canada and their green alternatives were calculated and their environmental impactswere studied. Lifecycle analysis of construction materials was conducted and their specific emergy was calculated using transformity functions. SimaPro was used as a tool to perform life cycle analysis of construction materials.

Results show that HVFA concrete has lower specific emergy compare to Portland cement concrete. Similarly, specific emergy of linoleum $\left(2.78 \times 10^{9} \mathrm{sej} / \mathrm{g}\right)$, as one of rapidly renewable materials suggested by LEED, is lower than ceramic tiles $\left(3.68 \times 10^{9} \mathrm{sej} / \mathrm{g}\right)$. Therefore, linoleum has lower impacts on the environment and is a sustainable optionfor flooring of green buildings.

However, specific emergy of bamboo $\left(4.37 \times 10^{9} \mathrm{sej} / \mathrm{g}\right)$ is much higher than plywood $\left(2.66 \times 10^{9} \mathrm{sej} / \mathrm{g}\right)$ in Canadian context. This is mainly due to long transportation distance from production location of bamboo in East Asia to the construction site in Canada. Although emergy due to transportation for locally produced materials is less than $1 \%$, it is high and influential for imported materials from long distances. Therefore, the rapidly renewable materials suggested by LEED, should not be chosen blindly without considering their overall environmental impacts. The main goal of LEED rating system is to classify sustainable structures. The case of bamboo indicated that LEED should categorize rapidly renewable materials suitable for different construction zones, rather than providing a general list.

The specific emergy of Portland cement concrete is $1.89 \times 10^{9} \mathrm{sej} / \mathrm{g}$. This value was compared to the specific emergy of concrete from different sources in the literature. It fits in the range $\left(7.34 \times 10^{8} \mathrm{sej} / \mathrm{g}\right.$ to $\left.3.70 \mathrm{x} 10^{9} \mathrm{sej} / \mathrm{g}\right)$, and close to the average value $\left(1.77 \times 10^{9} \mathrm{sej} / \mathrm{g}\right)$.

Considering the limited natural resources and the fact that building industry accounts for $40 \%$ of global material consumption, shift toward green buildings, that are made out of sustainable construction materials, is essential. Emergy analysis considers true environmental impact of construction materials and buildings. Therefore, an 'emergy-based building evaluation system' is a comprehensive and practical approach to measure sustainability performance of buildings and identifies green structures. 


\section{References}

Bamboo Technologies. (2011). Bamboo living. [Online] Available: http://www.bambooliving.com (March 1, 2011)

Bjorklund, J., Geber, U. \& Rydberg, T. (2001). Emergy analysis of municipal wastewater treatment and generation of electricity by digestion of sewage sludge. Resources, Conservation and Recycling, 31, 293-316. http://dx.doi.org/10.1016/S0921-3449(00)00091-4

Brown, M. T. \& Buranakarn, V. (2003). Emergy indices and ratios for sustainable material cycles and recycle options. Resources, Conservation and Recycling, 38 (1), 1-22. http://dx.doi.org/10.1016/S0921-3449(02)00093-9

Brown, M. T. \& Herendeen, R. (1996). Embodied energy analysis and emergy analysis: a comparative view. Ecological Economics, 19, 219-235. http://dx.doi.org/10.1016/S0921-8009(96)00046-8

Brown, M. T. \& McClanahan, T. R. (1992). Emergy analysis perspectives of Thailand and Mekong river dam proposals. Final Report to the Cousteau Society. Center for Wetlands and Water Resources, University of Florida, Gainesville, FL.

Buranakarn, V. (1998). Evaluation of recycle and reuse of building materials using the emergy analysis method (Ph.D. Dissertation). University of Florida, FL.

Chen, C., Habert, G., Bouzidi, Y., Jullien, A. \& Ventura, A. (2010). LCA allocation procedure used as an incitative method for waste recycling: Anapplication to mineral additions in concrete. Resources, Conservation and Recycling, 54, 1231-1240. http://dx.doi.org/10.1016/j.resconrec.2010.04.001

Chew, M. Y. L. \& Das, S. (2007). Building grading systems: a review of the state-of-art. Architectural Science Review, 51 (1), 3-13.

Jonsson, A., Tillman, A. M. \& Svensson, T. (1996). Life Cycle Assessment of Flooring Materials: Case Study. Building and Environment, 32 (3), 245-255. http://dx.doi.org/10.1016/S0360-1323(96)00052-2

Kubba, S. (2010). LEED practices, certification and accreditation handbook. Boston, MA: Elsevier. http://dx.doi.org/10.1016/B978-1-85617-691-0.00004-7

Lomborg, B. (2001). The Skeptical Environmentalist: Measuring the Real State of the World (pp. 138). Cambridge: Cambridge University Press.

Meillaud, F. \& Brown, M. T. (2005). Evaluation of a building using the emergy method. Solar Energy, 79, 204-212. http://dx.doi.org/10.1016/j.solener.2004.11.003

Mehta, K. (2002). Greening of the concrete industry for sustainable development. Concrete international, July, 23-28.

National Institute of Standards and Technology (NIST). (2003). Building for environmental and economic sustainability (BEES), model version 3.0., NIST, Gaithersburg, Md.

Newsham, G. R., Mancini, S. \& Birt, B. J. (2009). Do LEED-certified buildings save energy? yes, but... Energy and buildings, 41, 897-905. http://dx.doi.org/10.1016/j.enbuild.2009.03.014

Norman, J., MacLean, H. \& Kennedy, C. A. (2006). Comparing high and low residential density: life-cycle analysis of energy use and greenhouse gas emissions. Journal of urban planning and development, March, 10-21. http://dx.doi.org/10.1061/(ASCE)0733-9488(2006)132:1(10)

Odum, H. T. \& Arding, J. E. (1991). Emergy analysis of shrimp mariculture in Ecuador. Department of Environmental Engineering Sciences, University of Florida, Working Paper prepared for Coastal Resources Center, University of Rhode Island, Narragansett, RI.

Odum, H. T. (1992). Emergy and Public Policy.Part I-II, Environmental Engineering Sciences, University of Florida, Gainesville, FL.

Odum, H. T. (1996). Environmental accounting: emergy and environmental decision making. New York, NJ: Wiley. [Online] Available: http://www.peacefulresources.org/tag/linoleum (March 1, 2011)

Pulselli, R. M., Simoncini, E., Pulselli, F. M. \& Bastianoni, S. (2007). Emergy analysis of building manufacturing, maintenance and use: em-building indices to evaluate housing sustainability. Energy and Buildings, 39, 620-628. http://dx.doi.org/10.1016/j.enbuild.2006.10.004

Pulselli, R. M., Pulselli, F. M., Marchettini, N. \& Bastianoni, S. (2006). Sustainability concern of housing: emergy storage and flow assessment. In: Brebbia, C.A., Conti, M.E., Tiezzi, E. (Eds.), Natural Resources, 
Sustainable Development and Ecological Hazards (pp. 749-758). Southampton: WIT Press. http://dx.doi.org/10.2495/RAV060731

Pulselli , R. M., Simoncini, E., Ridolfi, S. \& Bastianoni, S. (2008). Specific emergy of cement and concrete: an energy-based appraisal of building materials and their transport. Ecological indicators, 8, 647-656. http://dx.doi.org/10.1016/j.ecolind.2007.10.001

Roodman, D. M. \& Lenssen, N. (1995). A building revolution: how ecology and health concerns are transforming construction. Worldwatch institute.

Tiezzi, E. (2001). Implementazione di un sistema di contabilita` ambientale su scalaprovinciale e intercomunale. Experimental project sponsored by Italian Minister for the Environment. University of Siena and Province of Bologna, Bologna, [Online] Available: http://www.provincia.bologna.it/ambiente/pdf_pubblicazioni/contabilita_ambientale.pdf

Tilley, D. R. \& Swank, W. T. (2003). Emergy based environmental system assessment of a multipurpose temperate mixed forest watershed of the southern Appalashian Mountains USA. Journal of Environmental Manage, 69, 213-227. http://dx.doi.org/10.1016/j.jenvman.2003.08.002

Ulgiati, S. (2000). Energy, Emergy and Embodied exergy: diverging or converging approaches? In: Brown M.T. (Ed.), Proc. of the First Biennial Emergy Analysis Research Conference, Centre for Environmental Policy, University of Florida, Gainesville.

Ulgiati, S., Odum, H. T. \& Bastianoni, S. (1994). Emergy use, environmental loading and sustainability. An emergy analysis of Italy. Ecological Modelling, 73, 215-268. http://dx.doi.org/10.1016/0304-3800(94)90064-7

Ulgiati, S., Odum, H. T. \& Bastianoni, S. (1993). Emergy analysis of Italian agricultural system: the role of energy quality and environmental inputs. In: Bonati, L., Cosentino, U., Lasagni, M., Moro, G., Pitea, D., Schiraldi, A. (Eds.), Proceedings of Second International Workshop-Trends in Ecological Physical Chemistry (pp. 187-215). Amsterdam, Netherlands: Elsevier.

U.S. Environmental Protection Agency (US EPA). (2009). Green building basic information. [Online] Available: http://www.epa.gov/greenbuilding/pubs/about.htm (December 10, 2009)

U.S. Green Building Council (USGBC). (2007). [Online] Available: www.usgbc.org/showfile.aspx?documentid=742\#8 (March 21, 2007)

U.S. Green Building Council (USGBC). (2009). LEED for new construction and major renovations. Washington, DC.

Van der Lugt, P., van den Dobbelsteen, A. A. J .F. \& Janssen, J. J. A. (2005). An environmental, economic and practical assessment of bamboo as a building material for supporting structures. Construction and building materials, 20, 648-656. http://dx.doi.org/10.1016/j.conbuildmat.2005.02.023

Vogtländer, J., van der Lugt P. \& Brezet, H. (2010). The sustainability of bamboo products for local and Western European applications.LCAs and land-use. Journal of Cleaner Production, 18, 1260-1269. http://dx.doi.org/10.1016/j.jclepro.2010.04.015

Yudelson, J. (2008). The green building revolution. Island press, Washington, WA. 
Table 1. Major building grading systems (Chew \& Das, 2007)

\begin{tabular}{|c|c|c|c|}
\hline Type & Year & Grading System & Country \\
\hline \multirow{4}{*}{ First generation } & 1981 & $\mathrm{R}-2000$ & Canada \\
\hline & 1989 & P-mark & Sweden \\
\hline & 1997 & ELO \& EM scheme & Denmark \\
\hline & 2001 & Energy Start & USA \\
\hline $\begin{array}{c}\text { Second } \\
\text { generation }\end{array}$ & 2000 & $\begin{array}{c}\text { Leadership in Energy and Environmental } \\
\text { Design (LEED) }\end{array}$ & USA \\
\hline \multirow{11}{*}{ Third generation } & 1990 & $\begin{array}{c}\text { Building Research Establishment } \\
\text { Environmental Assessment Method } \\
\text { (BREEAM) }\end{array}$ & UK \\
\hline & 1993 & $\begin{array}{l}\text { Building Environmental Performance } \\
\text { Assessment Criteria (BEPAC) }\end{array}$ & Canada \\
\hline & 1996 & $\begin{array}{l}\text { Hong Kong Building Environmental } \\
\text { Assessment Method (HK-BEAM) }\end{array}$ & Hong Kong \\
\hline & 2001 & Housing Quality Assurance Law (HQAL) & Japan \\
\hline & 2002 & Green Building Tool (GBTool) & International \\
\hline & 2002 & Global Environmental Method (GEM) & UK \\
\hline & 2003 & Green Star & Australia \\
\hline & 2004 & Green Globes & USA \\
\hline & 2004 & Go Green. Go Green Plus & Canada \\
\hline & 2004 & Maintainability Scoring System (MSS) & Singapore \\
\hline & 2005 & $\begin{array}{c}\text { National Australian Built Environment Rating } \\
\text { System (NABERS) }\end{array}$ & Australia \\
\hline Other & 2004 & $\begin{array}{l}\text { Comprehensive Assessment System for } \\
\text { building Environmental Efficiency (CASBEE) }\end{array}$ & Japan \\
\hline
\end{tabular}

The above table shows history of building rating systems since their inception in 1980s, their type and country of origin.

Table 2. Emergy studies related to construction industry in the literature

\begin{tabular}{|c|c|}
\hline \multirow{4}{*}{ Buildings and housing } & Buranakarn, 1998 \\
\cline { 2 - 2 } & Meillaud and Brown, 2005 \\
\cline { 2 - 2 } Concrete & Pulselli et al., 2006 \\
\hline \multirow{4}{*}{ Cown et al., 1992 } \\
\cline { 2 - 2 } & Burankarn, 1998 \\
\cline { 2 - 2 } & Bjorklund et al., 2001 \\
\cline { 2 - 2 } & Brown et al., 2003 \\
\cline { 2 - 2 } & Pulselli et al., 2007 \\
\hline
\end{tabular}

The above table refers to emergy studies related to building construction and materials that are available in the literature for further reading. 
Table 3. Mixture proportions for portland cement and HVFA concrete (compressive strength 25MPa) (Mehta, 2002)

\begin{tabular}{|c|c|c|}
\hline & \multicolumn{2}{|c|}{ Mass $\left(\mathrm{kg} / \mathrm{m}^{3}\right)$} \\
\hline & $\begin{array}{c}\text { Normal } \\
\text { concrete }\end{array}$ & $\begin{array}{c}\text { HVFA } \\
\text { concrete }\end{array}$ \\
\hline Cement & 307 & 154 \\
\hline Fly Ash & 0 & 154 \\
\hline Water & 178 & 120 \\
\hline Coarse aggregate & 1040 & 1210 \\
\hline Fine aggregate & 825 & 775 \\
\hline Total & 2350 & 2413 \\
\hline w/c ratio & 0.58 & 0.38 \\
\hline
\end{tabular}

The above table shows mixture proportions of Portland cement and HVFA concrete used in the analysis. This mixture leads to compressive strength of $25 \mathrm{MPa}$.

Table 4. Specific emergy of construction materials (LCA from SimaPro 7.1)

\begin{tabular}{|c|c|c|c|c|c|c|c|c|}
\hline & \multicolumn{3}{|c|}{ Currently used construction materials } & \multicolumn{3}{c|}{ Green materials } \\
\hline $\begin{array}{c}\text { Emergy input } \\
\text { (sej/g) }\end{array}$ & $\begin{array}{c}\text { Portland } \\
\text { cement } \\
\text { concrete }\end{array}$ & Plywood & $\begin{array}{c}\text { Structural } \\
\text { Steel }\end{array}$ & $\begin{array}{c}\text { Reinforcing } \\
\text { rebar }\end{array}$ & Brick & Bamboo & Linoleum & $\begin{array}{c}\text { HVFA } \\
\text { concrete }\end{array}$ \\
\hline Material & $1.38 \mathrm{e} 09$ & $1.99 \mathrm{e} 09$ & $7.27 \mathrm{e} 09$ & $7.48 \mathrm{e} 09$ & $2.33 \mathrm{e} 09$ & $1.33 \mathrm{e} 09$ & $1.24 \mathrm{e} 09$ & $1.31 \mathrm{e} 09$ \\
\hline Energy & $5.00 \mathrm{e} 08$ & $6.70 \mathrm{e} 08$ & $1.08 \mathrm{e} 09$ & $8.45 \mathrm{e} 08$ & $1.01 \mathrm{e} 08$ & $6.82 \mathrm{e} 08$ & $1.50 \mathrm{e} 09$ & $3.20 \mathrm{e} 07$ \\
\hline Transportation & $9.19 \mathrm{e} 06$ & $9.19 \mathrm{e} 06$ & $1.84 \mathrm{e} 07$ & $1.84 \mathrm{e} 07$ & $1.38 \mathrm{e} 07$ & $2.36 \mathrm{e} 09$ & $4.60 \mathrm{e} 07$ & $9.19 \mathrm{e} 06$ \\
\hline Human Work & $9.43 \mathrm{e} 02$ & $2.83 \mathrm{e} 03$ & $1.24 \mathrm{e} 03$ & $1.24 \mathrm{e} 03$ & $1.24 \mathrm{e} 03$ & $1.24 \mathrm{e} 03$ & $1.24 \mathrm{e} 03$ & $9.43 \mathrm{e} 02$ \\
\hline Total (sej/g) & $1.89 \mathrm{e} 09$ & $2.66 \mathrm{e} 09$ & $8.37 \mathrm{e} 09$ & $8.33 \mathrm{e} 09$ & $2.44 \mathrm{e} 09$ & $4.37 \mathrm{e} 09$ & $2.78 \mathrm{e} 09$ & $1.35 \mathrm{e} 09$ \\
\hline
\end{tabular}

The above table shows the result of emergy analysis performed for both conventional and green materials. Table is divided into four sections, showing emergy contribution from material, energy consumption, transportation and human work. The last row shows specific emergy of each construction materials used for 'discussion of result' section.

Table 5. Specific emergy of concrete obtained from various studies

\begin{tabular}{|c|c|}
\hline $\begin{array}{c}\text { Specific Emergy } \\
(\mathrm{sej} / \mathrm{g})\end{array}$ & Reference \\
\hline $1.06 \mathrm{E}+09$ & Brown and McClanahan (1992) \\
\hline $1.54 \mathrm{E}+09$ & Buranakarn (1998) \\
\hline $7.34 \mathrm{E}+08$ & Bjorklund et al. (2001) \\
\hline $3.70 \mathrm{E}+09$ & Brown and Buranakarn (2003) \\
\hline $1.81 \mathrm{E}+09$ & Pulselli et al. (2007) \\
\hline $1.89 \mathrm{E}+09$ & This study \\
\hline
\end{tabular}

The above table compares the specific emergy of Portland cement concrete found from this studies to the values available in the literature. Main reason for variation in these data arises from differences in type and properties of concrete, such as cement content, density and compressive strength. 


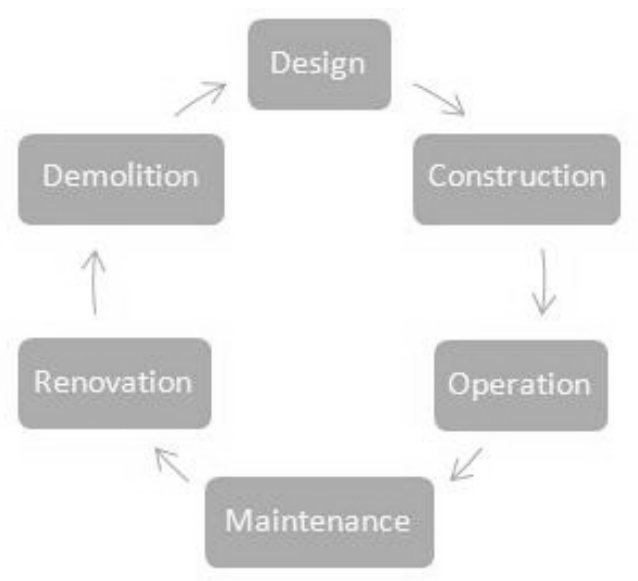

Figure1. Building life cycle

This figure shows different stages of building life cycle.

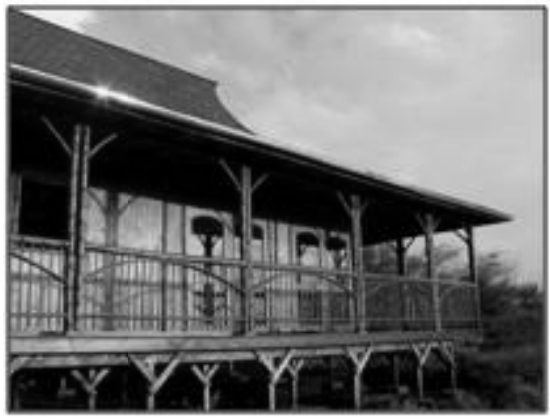

(a)

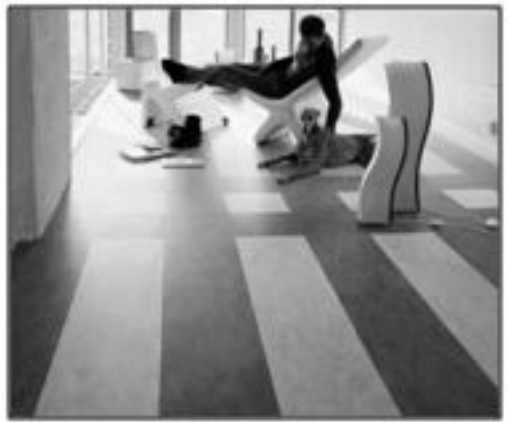

(b)

Figure 2. (a). Bamboo as structural material (Bamboo Technologies, 2011), (b). Linoleum as flooring material (Peaceful resources, 2011)

These images show use of rapidly renewable natural materials in buildings. Figures (a) and (b) show usage of bamboo as a load carrying (structural) material in a house and figure (c) shows linoleum used for flooring of a room.

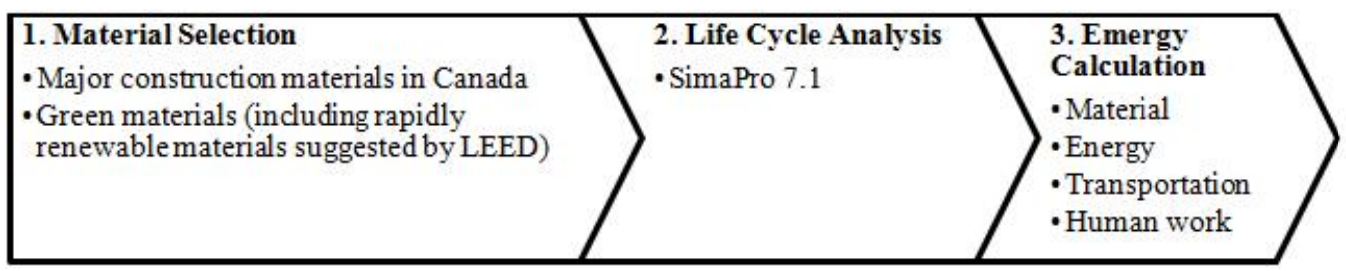

Figure 3. Methodology

The above figure shows methodology followed in this paper. 


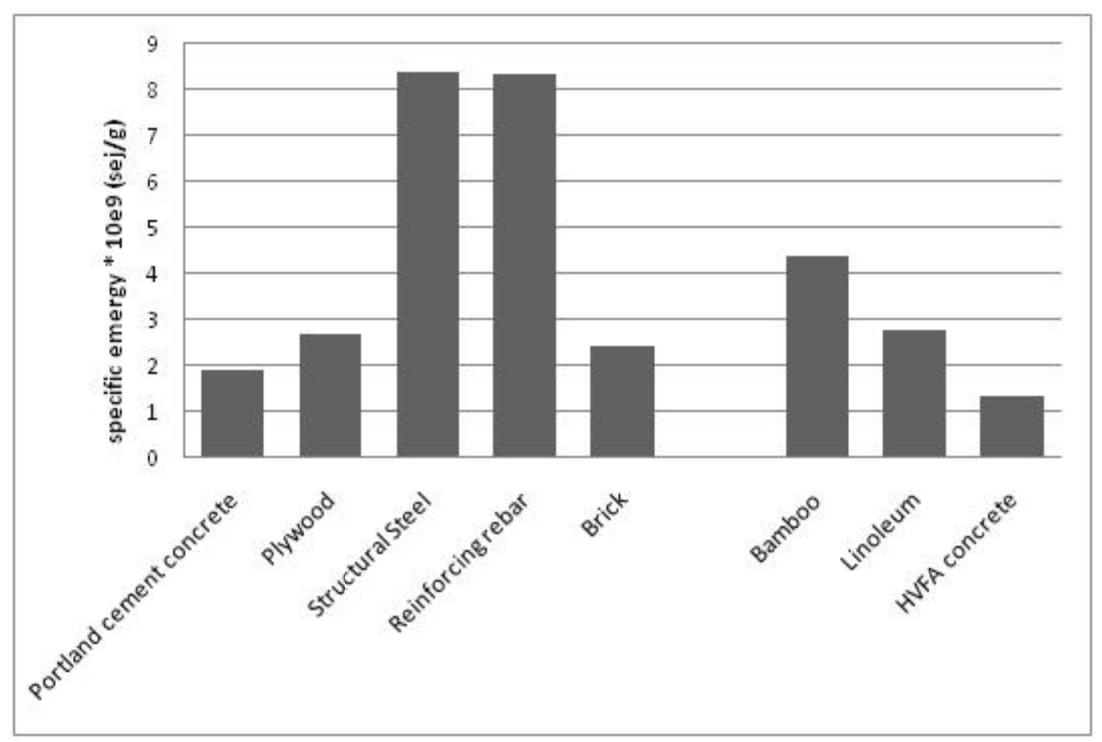

Figure 4. Specific emergy of construction materials

The above figure shows analysis result of this paper; specific emergy of conventional and green building materials.

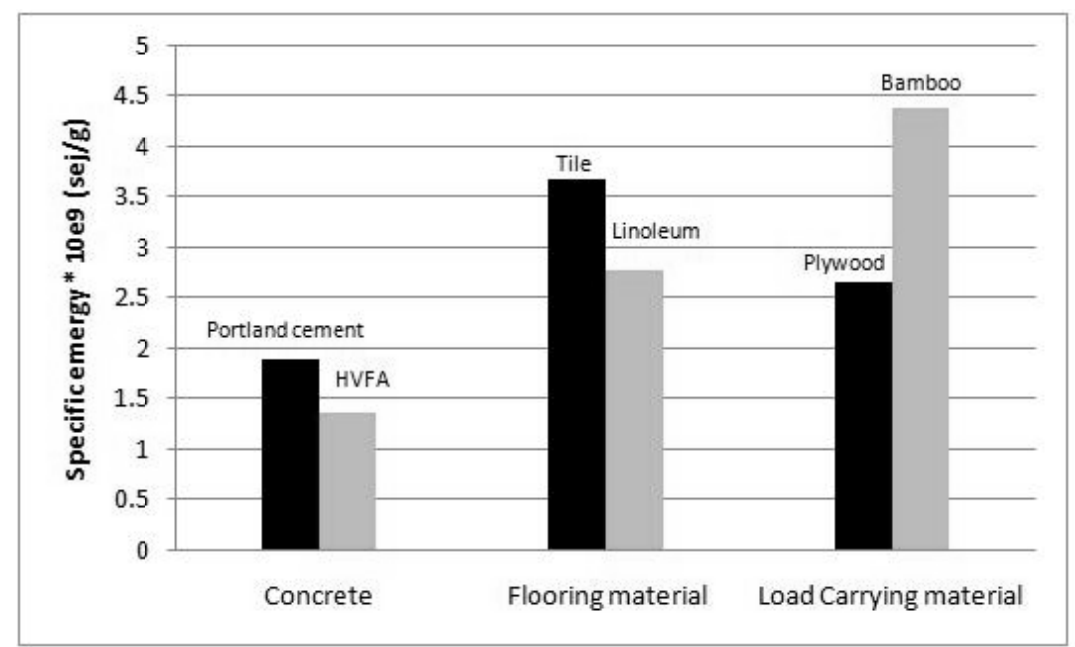

Figure 5. Specific emergy comparison of conventional and green materials

The above figure shows the comparison of specific emergy of conventional and green materials for various structural purposes. 